\title{
Soil Moisture-Boundary Layer Feedbacks on the Loess Plateau in China Using Radiosonde Data with 1-D Atmospheric Boundary Layer Model
}

\author{
Yingsai Ma ${ }^{1,2}$, Xianhong Meng ${ }^{1, *(D)}$, Yinhuan Ao ${ }^{1}$, Ye Yu ${ }^{1,3}$, Guangwei Li ${ }^{1,2}$, Shihua Lyu ${ }^{4}$, Jianglin Li ${ }^{1,3}$ \\ and Jie $\mathrm{Xu}{ }^{2,5}$ \\ 1 Key Laboratory of Land Surface Process and Climate Change in Cold and Arid Regions, \\ Northwest Institute of Eco-Environment and Resources, Chinese Academy of Sciences, \\ Lanzhou 73000, China; mayingsai@lzb.ac.cn (Y.M.); oyh@lzb.ac.cn (Y.A.); yyu@lzb.ac.cn (Y.Y.); \\ ligw@lzb.ac.cn (G.L.); lijl@lzb.ac.cn (J.L.) \\ 2 College of Earth and Planetary Sciences, University of Chinese Academy of Sciences, Beijing 100049, China; \\ xujie@itpcas.ac.cn \\ 3 Pingliang Land Surface Process and Severe Weather Research Station, Pingliang 744000, China \\ 4 Plateau Atmosphere and Environment Key Laboratory of Sichuan Province, School of Atmospheric Sciences, \\ Chengdu University of Information Technology, Chengdu 610200, China; slu@cuit.edu.cn \\ 5 State Key Laboratory of Tibetan Plateau Earth System, Resources and Environment, \\ Institute of Tibetan Plateau Research, Chinese Academy of Sciences, Beijing 100085, China \\ * Correspondence: mxh@lzb.ac.cn
}

Citation: Ma, Y.; Meng, X.; Ao, Y.; Yu, Y.; Li, G.; Lyu, S.; Li, J.; Xu, J. Soil Moisture-Boundary Layer Feedbacks on the Loess Plateau in China Using Radiosonde Data with 1-D Atmospheric Boundary Layer Model. Atmosphere 2021, 12, 1619. https:// doi.org/10.3390/atmos12121619

Academic Editor: Branko Grisogono

Received: 30 October 2021

Accepted: 2 December 2021

Published: 4 December 2021

Publisher's Note: MDPI stays neutral with regard to jurisdictional claims in published maps and institutional affiliations.

Copyright: (c) 2021 by the authors. Licensee MDPI, Basel, Switzerland. This article is an open access article distributed under the terms and conditions of the Creative Commons Attribution (CC BY) license (https:// creativecommons.org/licenses/by/ $4.0 /)$.
Abstract: The Loess Plateau is one land-atmosphere coupling hotspot. Soil moisture has an influence on atmospheric boundary layer development under specific early-morning atmospheric thermodynamic structures. This paper investigates the sensitivity of atmospheric convection to soil moisture conditions over the Loess Plateau in China by using the convective triggering potential (CTP) - humidity index $\left(\mathrm{HI}_{\text {low }}\right)$ framework. The CTP indicates atmospheric stability and the $\mathrm{HI}_{\text {low }}$ indicates atmospheric humidity in the low-level atmosphere. By comparing the model outcomes with the observations, the one-dimensional model achieves realistic daily behavior of the radiation and surface heat fluxes and the mixed layer properties with appropriate modifications. New CTP-HI $\mathrm{H}_{\text {low }}$ thresholds for soil moisture-atmosphere feedbacks are found in the Loess Plateau area. By applying the new thresholds with long-time scales sounding data, we conclude that negative feedback is dominant in the north and west portion of the Loess Plateau; positive feedback is predominant in the south and east portion. In general, this framework has predictive significance for the impact of soil moisture on precipitation. By using this new $\mathrm{CTP}-\mathrm{HI}_{\text {low }}$ framework, we can determine under what atmospheric conditions soil moisture can affect the triggering of precipitation and under what atmospheric conditions soil moisture has no influence on the triggering of precipitation.

Keywords: soil moisture; boundary layer; feedback; one-dimensional model; Loess Plateau

\section{Introduction}

The land processes and feedbacks are highly complex due to the substantial heterogeneity of the land cover and its temporal variability. The water stored on land is a crucial variable controlling numerous processes and feedbacks within the climate system $[1,2]$. The land surface and the atmosphere are closely linked through the exchange of energy and water. It has been recognized that soil moisture plays a vital role in this exchange through its impacts on surface albedo and the partitioning between sensible and latent heat fluxes [3-8].

The influences of soil moisture change on temperature and precipitation have been researched in many studies. Among these studies, the effects of soil moisture on the temperature at different temporal scales have been well documented $[9,10]$. However, 
significant uncertainties remain in the impacts on precipitation [11-13]. Most researches have explored the effects of soil moisture on rainfall using both observations and climate models [14-17]. However, the results from models and observations have produced inconsistent reports on the degree and even the direction of the feedbacks between the soil moisture condition and subsequent rainfall. Most explorations about soil moisture's influence on precipitation have focused on moisture recycling [18-20]. There has been increasing attention toward indirect soil moisture-precipitation feedbacks, in which the pathway refers to soil moisture's influence on boundary layer characteristics and the convective initiation.

There are generally two opposite feedbacks involved in the indirect soil moisturerainfall coupling, i.e., positive and negative feedback. Positive feedback occurs when wet soil enhances the convective available potential energy (CAPE). If the moisture rises to layers of conditional instability, the increased latent heat can improve the likelihood of convective triggering. Negative feedback occurs when high sensible heat flux increases planetary boundary layer growth, enabling penetration of the lifting condensation level and triggering moist convection and subsequent precipitation [21,22].

The couplings between the land surface and the atmosphere were found to be robust in semiarid ecosystems [23]. Model analyses about the sensitivity of temperature and precipitation to the land surface state concluded that the dry-wet transition area was a hotspot of coupling [24-26]. Our study focuses on the Loess Plateau region in China, which is the semiarid transition region between humid and arid climate regions. Moreover, Koster et al. [25] also identified this region was located on the hotspots of coupling. Furthermore, the vegetation cover has dramatically increased on the Loess Plateau since 1999 due to China's Grain for Green project. According to satellite imagery, the vegetation cover on the Loess Plateau area has almost doubled between 1999 and 2013 [27]. Therefore, exploring soil moisture-precipitation feedbacks has potential implications for this region.

Findell [28] used a single boundary layer model to determine the relative influences of soil moisture and entrainment fluxes on convective precipitation. They created the convective triggering potential (CTP) and the low-level humidity index $\left(\mathrm{HI}_{\text {low }}\right)$ framework to classify atmospheric conditions. They found that the soil moisture condition can trigger or prevent precipitation under certain atmospheric conditions, while the land surface condition was irrelevant under other situations. Ferguson and Wood [29] classified the land-atmosphere couplings using the CTP-HI $\mathrm{H}_{\text {low }}$ framework and relying on satellite remote sensing. They concluded that the proposed CTP-HI $\mathrm{H}_{\mathrm{low}}$ subspace was too rigid to be globally applicable. Tuinenburg et al. [22] calculated the CTP-HI low subspace in India following Findell's [28] work. They made slight modifications to the one-dimensional boundary layer model and suggested that different $\mathrm{CTP}-\mathrm{HI}_{\mathrm{low}}$ values should be adopted in India compared to the initial thresholds in the United States.

Our study investigates the CTP-HI $\mathrm{l}_{\text {low }}$ thresholds based on the single-model results with soundings from the Loess Plateau stations. We try to find differences in the framework values between the Loess Plateau region and other regions and what feedbacks can be expected in this region. By using this predictive CTP-HI low framework, we can determine under what atmospheric conditions soil moisture can promote or inhibit the triggering of precipitation and under what atmospheric conditions soil moisture has no influence on the triggering of precipitation. Due to the frequent occurrence of extreme weather in recent years, we can use the threshold obtained in the Loess Plateau to further predict the later convective precipitation and we believe that our work is of great significance to predict future precipitation.

The structure of this paper is as follows. The one-dimensional model and the CTP$\mathrm{HI}_{\text {low }}$ framework are introduced in Section 2. The modifications of the one-dimensional model, the data processing methods, and the data used in this study are presented in Section 3. Section 4 shows the evaluation of the slab model over the Loess Plateau by comparing the observations to the model simulation results. The feedback results of this research are presented in Section 5. The last section includes the discussion and the conclusion. 


\section{One-Dimensional Model and CTP-HI ${ }_{\text {low }}$ Framework}

\subsection{One-Dimensional Model}

This one-dimensional model is mainly about computing the daily variation of the four variables, i.e., soil temperature $\left(T_{S}\right)$, mixed-layer potential temperature $(\theta)$, mixed-layer specific humidity (q), and the mixed-layer height (h) [30,31]. To diagnose the boundary layer growth on days with different early-morning atmospheric conditions and dry or wet soil conditions, Findell and Eltahir [32] made some alterations to the original model and built the CTP-HI $\mathrm{H}_{\text {low }}$ framework. The model runs based on four main assumptions, i.e., the atmospheric boundary layer is ideal for mixing, the overlying air is considered constant, cloud-free, and soil moisture is constant during the simulation [22,32].

The lapse rates of potential temperature and specific humidity were acquired from the early morning sounding measurements to determine the entrainment. Three possible outcomes of each model run: deep convection, shallow convection and no convection. Rain can occur when the CAPE is more than $400 \mathrm{~J} / \mathrm{kg}$ and the depth of convection is greater than $5 \mathrm{~km}$ and these threshold values are appropriate for the mid-latitude continental regions [33]. Hereafter, we use the single model to determine the Loess Plateau area's atmospherically-controlled and soil moisture-controlled cases. The atmosphericallycontrolled cases refer to rain in both wet and dry conditions, shallow convection in both soil conditions, and no convection over wet and dry soil conditions. In contrast, soil moisture-controlled cases refer to different outcomes over different soil conditions.

\subsection{CTP-HI $\mathrm{I}_{\text {low }}$ Framework}

The CTP is calculated by integrating the area between the environmental temperature and the moist adiabatic profile between $100 \mathrm{mb}$ and $300 \mathrm{mb}$ above the ground surface. It measures atmospheric stability, ruling out convection in stable conditions, as many traditional stability indices do (e.g., Showalter index [34]). $\mathrm{HI}_{\text {low }}$ is defined as the sum of the temperature and dewpoint depressions between 50 and $100 \mathrm{mb}$ above the ground surface. This is the humidity index in the lower level of the atmosphere and is designed to determine the possibility of rain for an atmospheric profile. For a more detailed introduction and calculation formulas of $\mathrm{CTP}-\mathrm{HI}_{\text {low }}$ indicators, the reader is referred to [32].

\section{Data and Methods}

\subsection{Modifications of the One-Dimensional Model}

We considered the time scale for the slab model simulation on $12 \mathrm{~h}$, i.e., 8:00 a.m. to 7:00 p.m. local times. The model was initiated by the early morning soundings (0000UTC, 0800 local times) in the Loess Plateau and proceeded until $12 \mathrm{~h}$ later or the initiation of free convection.

The observations showed that soil saturation in the Loess Plateau usually changes from 0.1 to 0.6 (Figure 1). An extremely dry and an extremely wet soil saturation were set to 0.1 and 0.8 separately for each sounding on the basis of these changes in this semiarid region. Noted modifications in the slab model were the calculations about the stomatal resistance in the dry and wet soil conditions. Realistic evapotranspiration in different soil conditions could be achieved using a minimum stomatal resistance of about $50 \mathrm{~s} / \mathrm{m}$ and maximum stomatal resistance of about $2500 \mathrm{~s} / \mathrm{m}$ [28]. Based on these modifications, the midday Bowen ratio in the model experiments changed from 1.0-2.0 in the extremely dry cases and a range of $0.1-0.2$ in the extremely wet cases. Moreover, we determined the incoming solar radiation based on the day of the year and the geographic location of the atmospheric soundings in the present study. 


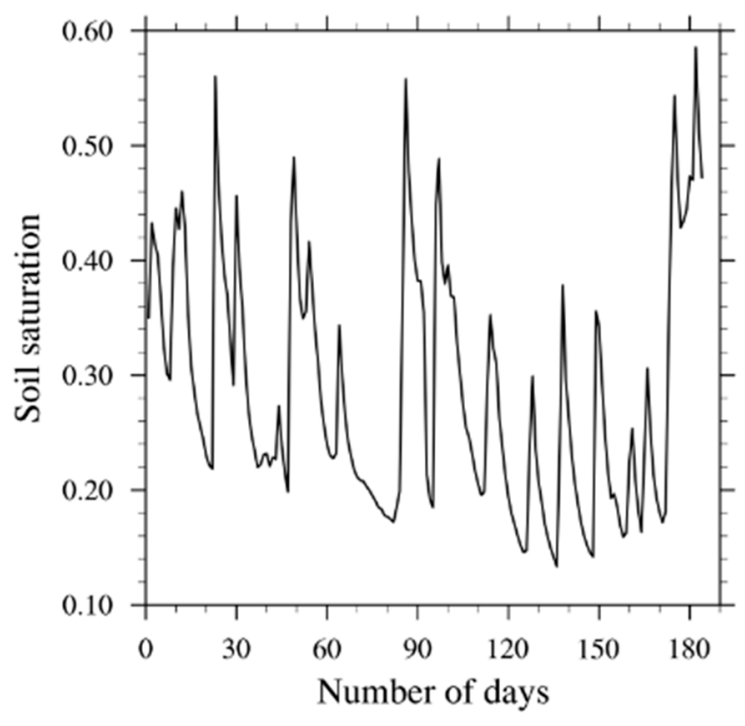

Figure 1. Value distribution of daily soil saturation in two summers (i.e., 184 days) of 2016-2017 at Pingliang station.

\subsection{Data}

The observation data used to evaluate the model are from the Pingliang land surface process and severe weather research station (hereafter referred to as Pingliang station) (Figure 2), which belonged to the Chinese Academy of Sciences. Here we select two cloudless days' data, including the radiation flux, the sensible and latent heat flux, surface temperature data with 30-min intervals, and the radiosonde data at four times $(0800,1100$, 1400, 1700 local times). The soil moisture measurements used to judge the soil saturation thresholds are from observations taken in two summers of 2016-2017 in Pingliang station. Furthermore, the sounding data used to initiate the model are from radiosondes launched at 0000 UTC (0800 local times) from five meteorological stations (Figure 2) over the Loess Plateau during the summertime (June, July, August) of 2006-2019. The sounding data used to diagnose the positive and negative feedback distributions in climatic scales are from eight meteorological stations (Figure 3) during the summertime of 1974-2019. These sounding data were acquired from the University of Wyoming (available online at http:/ / weather.uwyo.edu/upperair/sounding.html, accessed on 29 June 2021) [22].
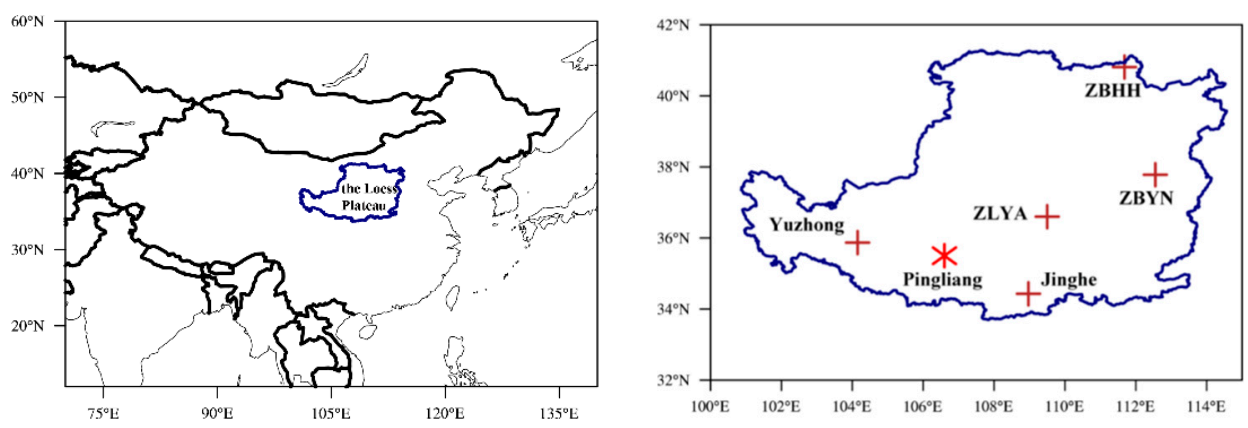

Figure 2. Locations of the six stations. Five cross markers indicate stations with only initial sounding data (at 08:00 LT). The star marker indicates Pingliang station with soil moisture, fluxes and radiosonde observations. 


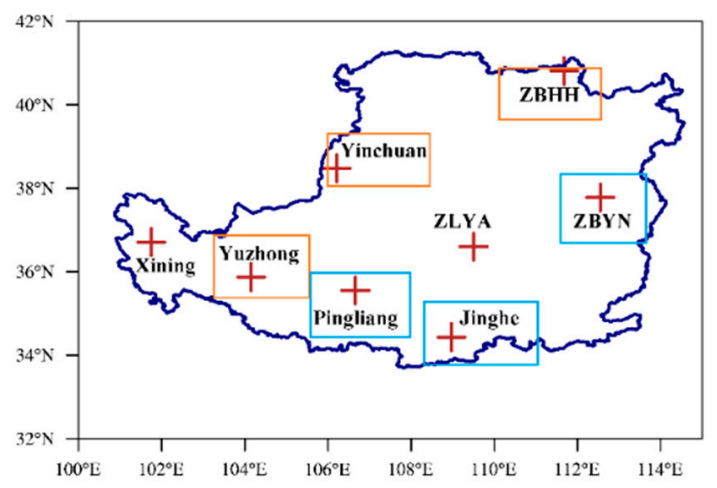

Figure 3. Locations of the eight stations with long time scales (1974-2019) sounding data. Blue boxes indicate the majority area of positive feedbacks, and orange boxes indicate the majority area of negative feedbacks.

\subsection{Data Processing Methods}

The soil moisture observations in the summers during 2016-2017 in Pingliang station are taken half-hourly and are volumetric water content data, and we aggregated these half-hourly data into daily time series. Soil moisture can be considered as constant in a diurnal variation. According to the calculation formula: $W=\theta / \theta_{s}$, where $W$ is the soil saturation, $\theta$ is the volumetric water content $\left(\mathrm{m}^{3} / \mathrm{m}^{3}\right)$, and $\theta_{\mathrm{s}}$ is the saturated water content, or the total porosity [35]. In this research, we use the total porosity as 0.515 , the calculated value based on observations [36]. As Figure 1 shows, of the total 184 days, the daily soil saturation changes from 0.15 to 0.60 . Although these data are from only two summers, it is reasonable to set the extremely dry and highly wet soil saturation to 0.1 and 0.8 .

The sounding data used to initiate the model were selected by the following criteria $[22,28]$ :

- $\quad$ no rain or heavy cloud at the sounding time;

- no super-adiabatic surface layer present in the sounding;

- more than 20 vertical levels in the lower $400 \mathrm{hPa}$ of the sounding.

According to the selection criteria stated above, we acquired 537 available soundings from five stations in the summers of 2006-2019 for the Loess Plateau area. Using the new $\mathrm{CTP}-\mathrm{HI}_{\text {low }}$ thresholds of model outcomes, we further calculated the positive and negative feedback distributions in climatic scales with sounding data from eight meteorological stations (Figure 3) during the summertime of 1974-2019. These data were selected with a less strict criterion, i.e., the sounding with more than 10 layers in the lower $400 \mathrm{hpa}$ [22]. According to this criterion, we acquired a total of 5307 soundings.

\section{Model Verification}

To evaluate the model's performance, we compared the vertical structure of the model with observations as the boundary layer grows up. Here we chose two cloudless days, i.e., 28 June 2016 and 9 July 2017, which included the radiation flux, the sensible and latent heat flux, surface temperature data with 30-min intervals, and radiosonde data at $8,11,14$, and 17 local times. The simulation results for 28 June 2016 are presented in Figure 4, and the day 9 July 2017 are shown in Figure 5. According to the observed 5-cm depth soil moisture, the model ran with a soil saturation of 0.33 for 28 June 2016 and 0.19 for 9 July 2017. These two examples both show that the observed mixed layer properties fell within the realm of the properties obtained from running the model. The model results in Figure $4 \mathrm{a}-\mathrm{c}$ matched the observations of the boundary layer height, potential temperature, and specific humidity better than those in Figure 5a-c at the four sounding times. The boundary layer height from both two simulations was slightly over-predicted. In addition, the simulated mixed layerspecific humidity in Figure 5c was much higher than the observed value. Comparing the model results to the hourly measurements, we can conclude that the model has achieved natural daily radiation and eddy heat fluxes. The model results in Figure $4 \mathrm{~d}-\mathrm{i}$ were better 
than Figure $5 d-i$. The simulated net longwave radiations in Figure $5 \mathrm{~d}$ were somewhat more extensive, explaining the slight overestimation of net radiation (Figure $5 \mathrm{f}$ ). Bowen ratios were all overestimated compared with the observations because of the overestimation of sensible heat fluxes. The surface temperature in Figure $5 \mathrm{j}$ seemed to be poorer simulated than Figure $4 \mathrm{j}$, and the simulated values were much lower than the observations.
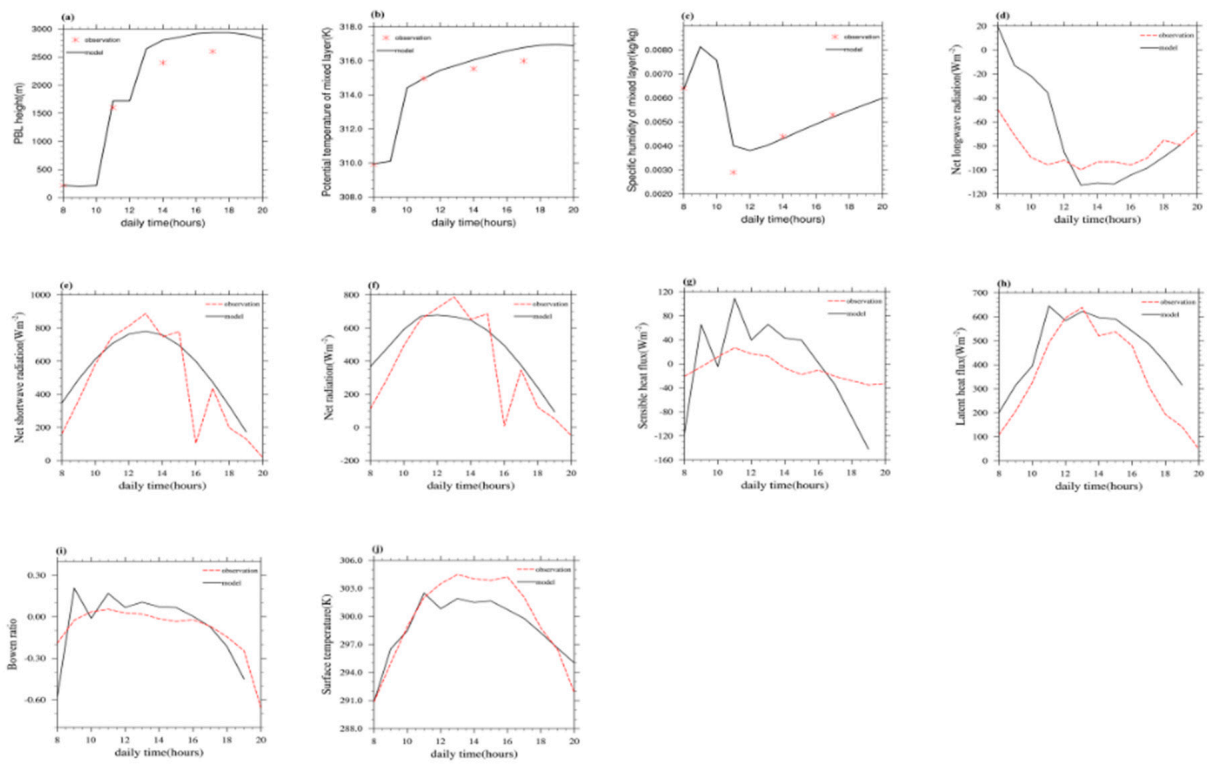

Figure 4. Verifications of simulated PBL height, potential temperature, specific humidity of mixed layer, net longwave radiation, net shortwave radiation, net radiation, sensible heat flux, latent heat flux, Bowen ratio, and surface temperature against observations using data from 28 June 2016, with soil saturation 0.33. (a): planetary boundary layer height (b): planetary boundary layer potential temperature (c): planetary boundary layer specific humidity (d): net longwave radiation (e): net shortwave radiation (f): net radiation (g): sensible heat flux (h): latent heat flux (i): Bowen ratio $(\mathbf{j})$ : surface temperature.
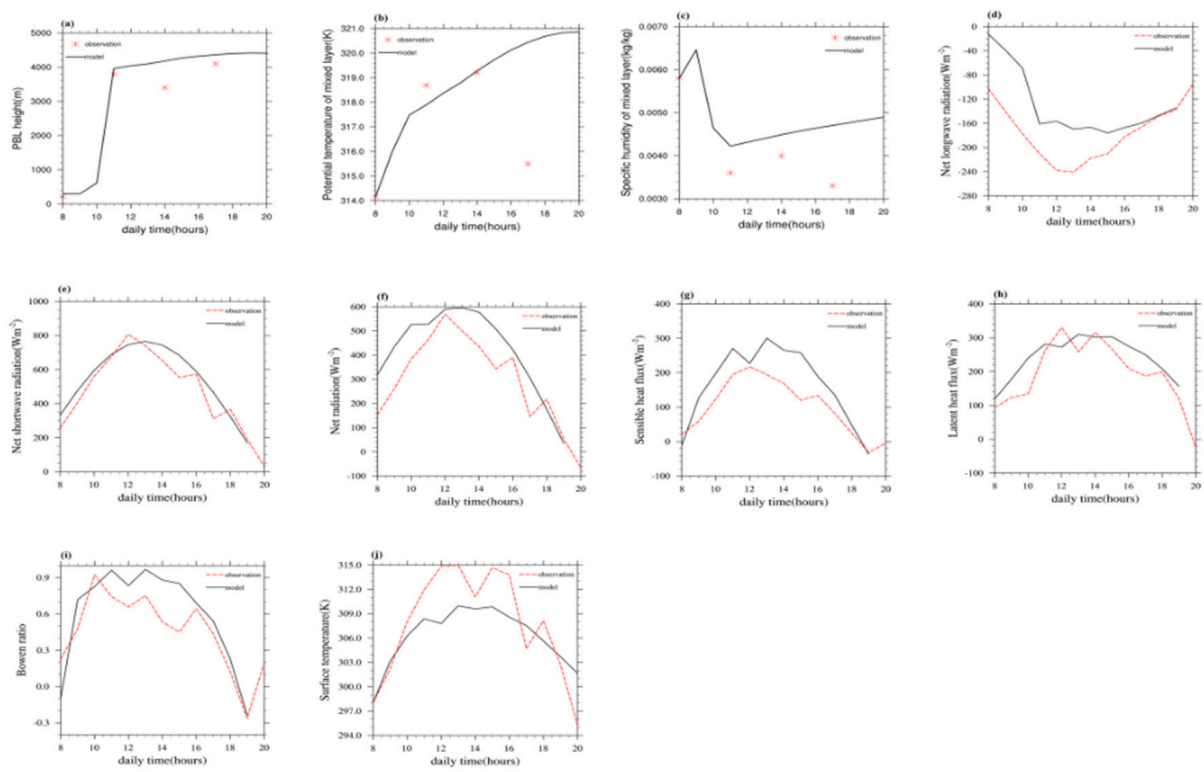

Figure 5. As in Figure 4, but for 9 July 2017, with soil saturation 0.19. (a): planetary boundary layer height (b): planetary boundary layer potential temperature (c): planetary boundary layer specific humidity $(\mathbf{d})$ : net longwave radiation (e): net shortwave radiation $(\mathbf{f})$ : net radiation $(\mathbf{g})$ : sensible heat flux (h): latent heat flux (i): Bowen ratio (j): surface temperature. 
Overall, the model results and the observations were consistent. As Findell (2001) illustrated, we did not tune the model to replicate observed days since our intent is not to use this model as a predictive tool. Thereby we will use this modified single model in the following work.

\section{Results}

\subsection{Soil Moisture-Atmosphere Feedbacks on the Loess Plateau}

Here we show the CTP-HI $\mathrm{H}_{\text {low }}$ scopes of atmospherically-controlled and soil moisturecontrolled cases of the five stations on the Loess Plateau. As shown in Figure 2, the five stations are located in different areas of the Loess Plateau. Station ZBHH is located at a latitude of $40.81^{\circ} \mathrm{N}$, on the northeast edge of the Loess Plateau area. The elevation of this station is $1065 \mathrm{~m}$, resulting in a surface pressure of about $880 \mathrm{hPa}$. A total of 74 available soundings in 2013-2019 were used to initiate the one-dimensional model. Station ZBYN is at a latitude of $37.78^{\circ} \mathrm{N}$ in Taiyuan, Shanxi Province of China. The elevation and surface pressure of this station are about $779 \mathrm{~m}$ and $920 \mathrm{hPa}$. The 72 soundings with no rainy and no super-adiabatic surface layer used to initiate the model were from 2013-2019. Station ZLYA is located at Yanan, Shaanxi Province of China, with a latitude of $36.6^{\circ} \mathrm{N}$. The elevation and surface pressure of this station are about $960 \mathrm{~m}$ and $876 \mathrm{hPa}$, respectively. The 156 available soundings from the summers of 2011-2019 were used to initiate the one-dimensional model. Station Yuzhong is located in Lanzhou, Gansu Province of China, with a latitude of $35.87^{\circ} \mathrm{N}$. The elevation and surface pressure of this station are about $1875 \mathrm{~m}$ and $806 \mathrm{hPa}$. In total, 170 available and non-rainy soundings from the summers of 2006-2019 were used to initiate the slab model. Station Jinghe is located in Xian, Shaanxi Province of China, with a latitude of $34.43^{\circ} \mathrm{N}$. The elevation and surface pressure of this station are about $411 \mathrm{~m}$ and $957 \mathrm{hPa}$. A total of 65 available and non-rainy soundings from the summers of 2009-2019 were used to initiate the one-dimensional model.

As illustrated in Figure 6a, we can clearly distinguish atmosphere-controlled cases from soil moisture-controlled cases. According to Figure $6 \mathrm{~b}$, we summarized that for atmosphere-controlled cases: when $\mathrm{HI}_{\text {low }}<10^{\circ} \mathrm{C}, \mathrm{CTP}<100 \mathrm{~J} / \mathrm{kg}$, shallow clouds are present across both soil conditions; when $\mathrm{HI}_{\text {low }}<10{ }^{\circ} \mathrm{C}$, CTP $>100 \mathrm{~J} / \mathrm{kg}$, there is rain over both soil conditions; and $\mathrm{HI}_{\text {low }}>26^{\circ} \mathrm{C}$, any CTP, there is no convection over either soil condition. According to Figure $6 \mathrm{c}$, we concluded that for soil moisture-controlled cases: when $10^{\circ} \mathrm{C}<\mathrm{HI}_{\text {low }}<16^{\circ} \mathrm{C}, \mathrm{CTP}<100 \mathrm{~J} / \mathrm{kg}$, shallow clouds occur over wet soils; $10^{\circ} \mathrm{C}<\mathrm{HI}_{\text {low }}<16^{\circ} \mathrm{C}, 100<\mathrm{CTP}<240 \mathrm{~J} / \mathrm{kg}$, there is a wet soil advantage, i.e., rain or shallow clouds over wet soils only; when $16{ }^{\circ} \mathrm{C}<\mathrm{HI}_{\text {low }}<26{ }^{\circ} \mathrm{C}, 100<\mathrm{CTP}<240 \mathrm{~J} / \mathrm{kg}$, there is a transition zone, and any outcome is possible; and $16{ }^{\circ} \mathrm{C}<\mathrm{HI}_{\text {low }}<26^{\circ} \mathrm{C}$, $240<\mathrm{CTP}<400 \mathrm{~J} / \mathrm{kg}$, there is a dry soil advantage, i.e., rain or shallow clouds over dry soils only.
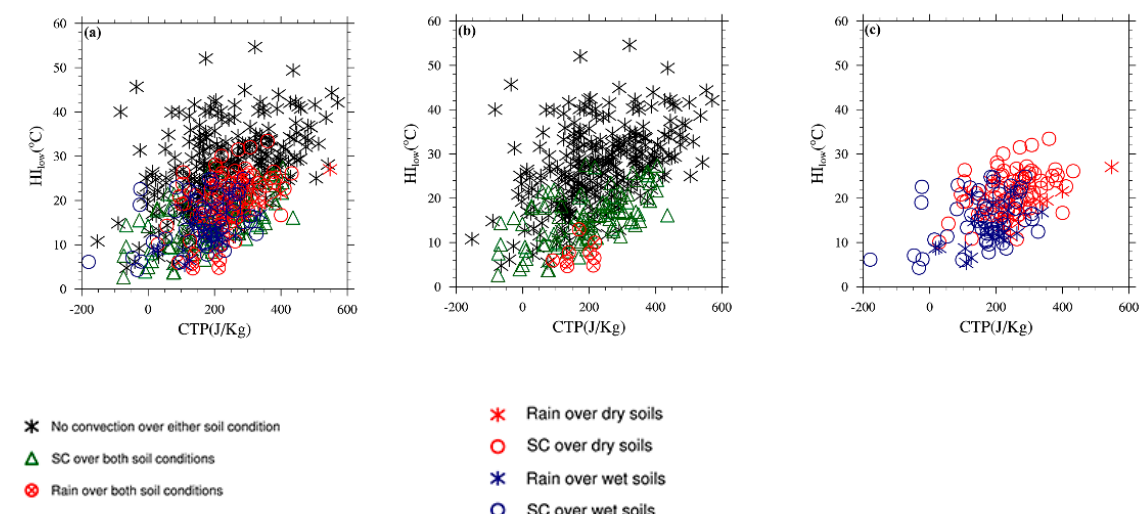

$$
\begin{aligned}
& \text { * Rain over dry soils } \\
& \text { O SC over dry soils } \\
& \text { * Rain over wet soils } \\
& \text { O SC over wet soils }
\end{aligned}
$$

Figure 6. The $\mathrm{CTP}-\mathrm{HI}_{\mathrm{low}}$ distributions of five stations' model outcomes in the Loess Plateau. Total cases: (a) atmosphere-controlled cases, (b) and soil moisture-controlled cases, (c) SC indicates shallow convection. Black boxes encircle wet soil advantage area and dry soil advantage area. 
Figure 7 illustrates the probability distributions of the atmosphere-controlled cases and soil moisture-controlled cases of the model's outcomes. Of the total 537 soundings, $69.83 \%$ were atmosphere-controlled cases, and $30.17 \%$ were soil moisture-controlled cases; for atmosphere-controlled cases, $49.53 \%$ were both no convection, $18.62 \%$ were both shallow convection, and $1.68 \%$ cases involved both spots of rain in wet and dry soil conditions (Figure 7a). For the total of 162 soil moisture-controlled cases, rain over dry soils occupied $12.35 \%$, shallow convection over dry soils occupied $43.21 \%$, rain over wet soils occupied $13.58 \%$, and shallow convection over wet soils occupied 30.86\% (Figure $7 \mathrm{~b}$ ). In total, positive feedback cases (rain or shallow convection over wet soils) were $44.44 \%$, compared to $55.56 \%$ of negative feedback cases (rain or shallow convection over dry soils).
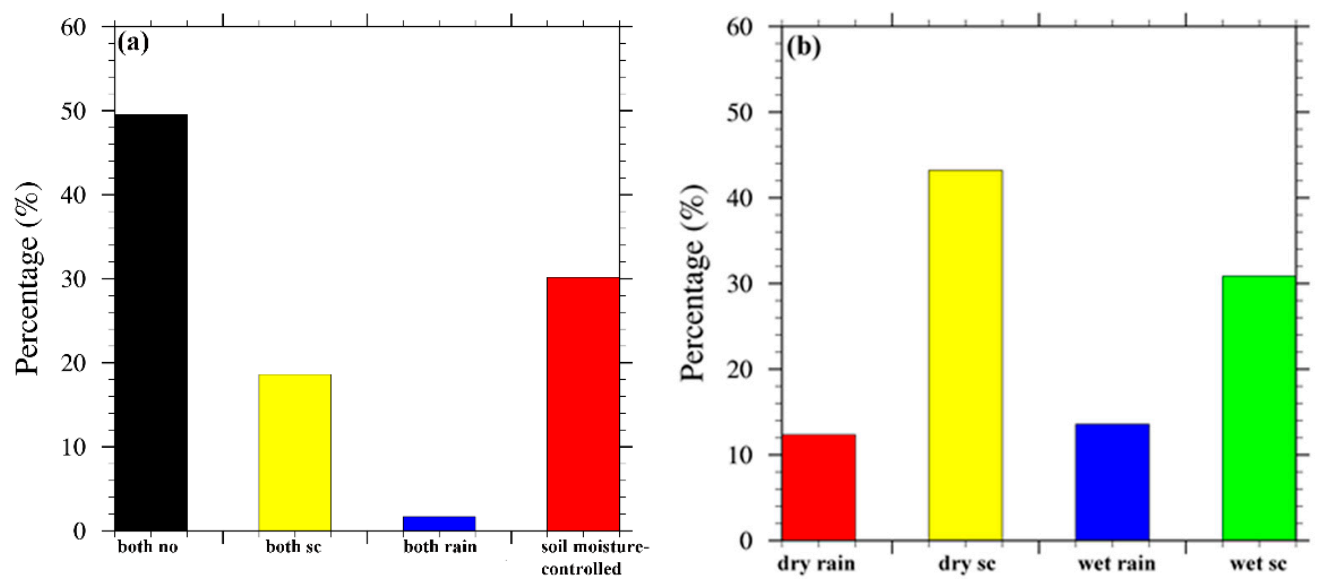

Figure 7. The probability distributions of atmosphere-controlled cases (a) and soil moisture-controlled cases (b).

\subsection{Distributions of Maximal Boundary Layer Height in Wet and Dry Soils}

As shown in Figure 8, the daily maximal boundary layer height in dry soils was much higher than in wet soils. The minimum values, lower quartile, median, upper quartile, and maximum values of the boundary layer height when there were wet soil advantage cases were $931.26 \mathrm{~m}, 2139.28 \mathrm{~m}, 2430.83 \mathrm{~m}, 2681.49 \mathrm{~m}$, and $3556.34 \mathrm{~m}$, respectively. The five values in the dry soil advantage cases were $1641.92 \mathrm{~m}, 3147.97 \mathrm{~m}, 3782.4 \mathrm{~m}$, $4863.06 \mathrm{~m}$, and $7067.31 \mathrm{~m}$, respectively. The average maximal boundary layer height values were $2431.86 \mathrm{~m}$ in the wet soil advantage cases compared to $3531.52 \mathrm{~m}$ in the dry soil advantage cases. These results verified that our model outcomes were reasonable. When the soil was dry, the sensible heat fluxes were high enough to increase the boundary layer height; when the soil was wet, the boundary layer grew more slowly, leading to a lower boundary layer height.

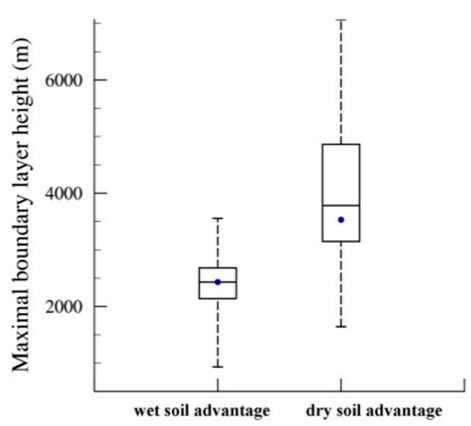

Figure 8. Distributions of maximal boundary layer height in wet soil advantage cases and dry soil advantage cases. The upper and lower of the box show upper quartile and lower quartile, and the line inside represents the median. The upper whisker and lower whisker indicate the maximum and the minimum values in the non-abnormal range, respectively. The blue spot is the average. 


\subsection{Atmosphere Background Influences on the Outcomes}

Any outcomes are in the scope of the atmospheric background, for example, when the atmosphere is too dry to generate clouds, it is necessary to check the atmospheric condition in these different outcomes. Due to a limitation of the observation, we only checked the humidity and wind influences. Distributions of the near-surface (generally 2-10 m above the ground surface in different stations) specific humidity and wind speed at the initial sounding times are shown in Figure 9 for different model outcomes (i.e., both rain in wet and dry soil conditions, both shallow clouds in wet and dry soil conditions, no rain in either wet or dry soil conditions, rain in dry soil conditions, shallow clouds in dry soil conditions, rain in wet soil conditions, shallow clouds in wet soil conditions).
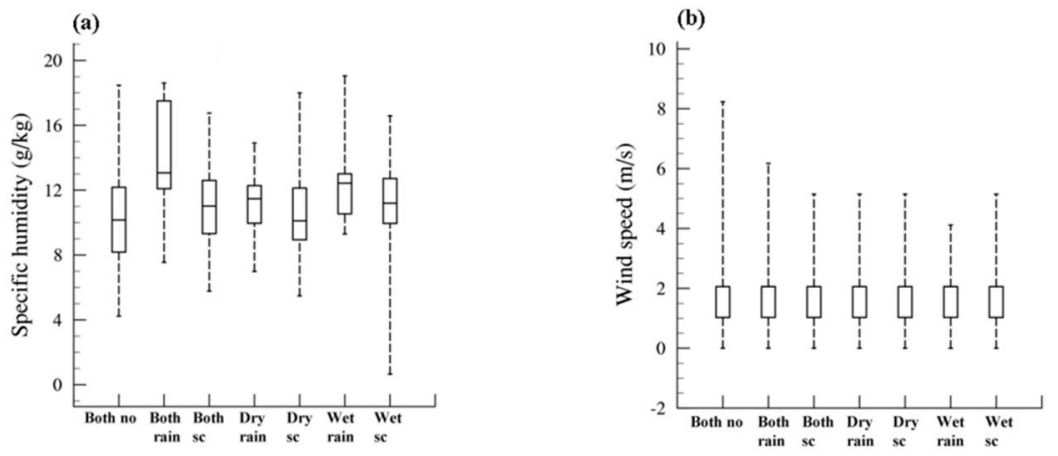

Figure 9. The distributions of near-surface specific humidity and wind speed at initial sounding times based on different model outcomes. The upper and lower of the box show upper quartile and lower quartile, and the line inside represents the median. The upper whisker and lower whisker indicate the maximum and the minimum values in the non-abnormal range, respectively. (a): nearsurface specific humidity (b): near-surface wind speed.

As is depicted in Figure 9a, the near-surface specific humidity showed different distributions in different model outcomes. In both-rain conditions, the specific humidity was significantly higher than in both-no conditions. In soil moisture-controlled conditions, the specific humidity in the dry soil advantage condition was lower than in the wet soil advantage condition. These humidity distributions were consistent with the $\mathrm{HI}_{\text {low }}$ distributions in different model outcomes, as stated above.

The distributions of the near-surface wind speed in Figure $9 \mathrm{~b}$ suggested low wind speeds at the initial sounding times. Therefore, in the calculations of aerodynamic resistance near the surface, we ignored the changes of wind speed, assuming that the model was permanently neutral, and set the aerodynamic resistance as constant [28]. The work of Findell [28] demonstrated that the three-dimensional wind configuration could enhance or diminish convective triggering. In this work, wind speed is relatively low in most cases, so we omitted the influence of wind and focused on the soil conditions' impact. Further work needs to be done considering more influences based on detailed field observational experiments.

\subsection{Positive and Negative Feedback Distributions in Climate Scales}

Based on the above model results, we applied the new $\mathrm{CTP}-\mathrm{HI}_{\text {low }}$ thresholds (i.e., $10{ }^{\circ} \mathrm{C}<\mathrm{HI}_{\text {low }}<16{ }^{\circ} \mathrm{C}, 100<\mathrm{CTP}<240 \mathrm{~J} / \mathrm{kg}$, wet soil advantage; $16{ }^{\circ} \mathrm{C}<\mathrm{HI}_{\text {low }}<26{ }^{\circ} \mathrm{C}$, $240<\mathrm{CTP}<400 \mathrm{~J} / \mathrm{kg}$, dry soil advantage) to explore the positive and negative feedback distributions in different areas of the Loess Plateau using long time scales sounding data. Due to using less strict criteria than the model's initial standards, we acquired 5307 soundings from eight meteorological stations (Figure 3) during the summertime of 1974-2019. In addition to the five stations stated above, the other three stations were added. The three stations were Yinchuan, Xining, and Pingliang. Station Yinchuan is at a latitude $38.47^{\circ} \mathrm{N}$ in Ningxia Hui Autonomous Region of China. The elevation and surface pressure of this station are about $1112 \mathrm{~m}$ and $886 \mathrm{hPa}$. Station Xining is at a latitude of $36.7^{\circ} \mathrm{N}$ in Qinghai 
province of China. The height and surface pressure of this station are about $2296 \mathrm{~m}$ and $773 \mathrm{hPa}$. Station Pingliang, which was used to evaluate the model as stated above, is at a latitude of $35.54^{\circ} \mathrm{N}$ in China's Gansu province. The elevation and surface pressure of this station are about $1348 \mathrm{~m}$ and $865 \mathrm{hPa}$.

The probability distributions of the wet soil advantage cases and dry soil advantage cases of the model's outcomes showed some difference from the new CTP-HI ${ }_{\text {low }}$ diagnostic results (Figure 10). For the model's outcomes (Figure 10a): from station ZBHH, a total of 74 soundings were obtained, and of these $13.51 \%$ were wet soil advantage cases, and $17.57 \%$ were dry soil advantage cases; from station Jinghe, a total of 65 cases were obtained, and of these $13.85 \%$ were wet soil advantage cases, and $18.46 \%$ were dry soil advantage cases; from station ZBYN, a total of 72 cases were obtained, and of these $18.06 \%$ were positive feedbacks, and $23.61 \%$ were negative feedbacks; from station ZLYA, a total of 156 cases were observed, and of these $11.54 \%$ were positive feedbacks, and $16.03 \%$ were negative feedbacks; and from station Yuzhong, a total of 170 cases were observed, and of these $12.94 \%$ were wet soil advantage cases, and $13.53 \%$ were dry soil advantage cases. The total percentage of positive feedbacks and negative feedbacks was $13.41 \%$ and $16.76 \%$, respectively. It appears that stations ZBHH, Jinghe, ZBYN, ZLYA had more negative feedbacks, and the total percentage indicated that more negative feedbacks existed in the Loess Plateau.
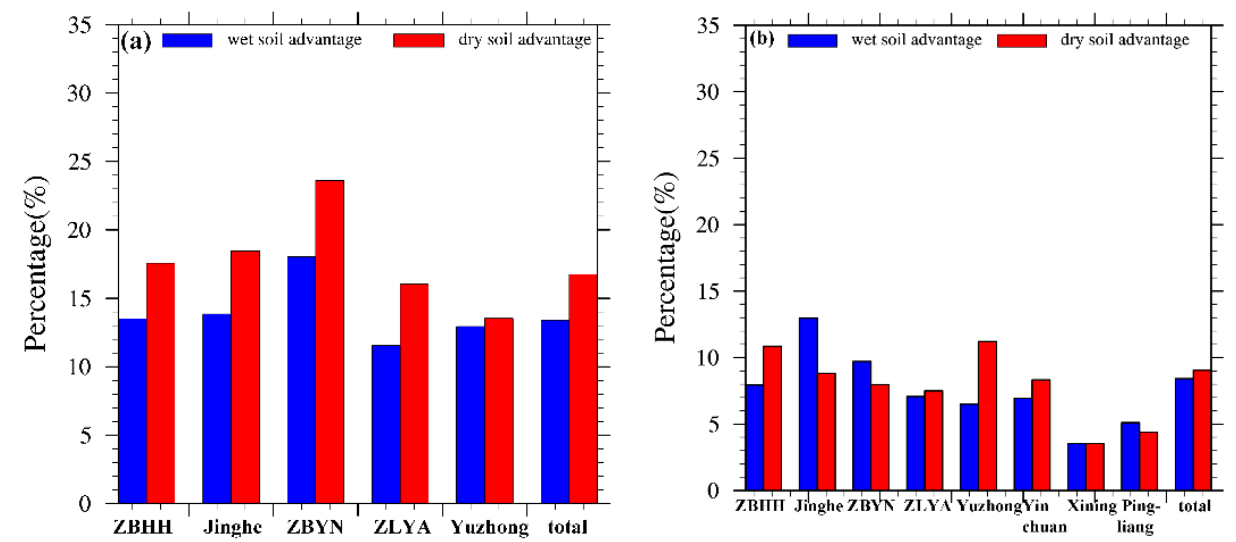

Figure 10. The probability distributions of wet soil advantage cases and dry soil advantage cases of model outcomes (a) and CTP-HI low diagnostic results (b).

For the new $\mathrm{CTP}-\mathrm{HI}_{\text {low }}$ diagnostic results which are based on long time scales (Figure 10b): from station $\mathrm{ZBHH}$, a total of 1210 cases were observed, and of these positive feedbacks occupied 7.93\%, and negative feedbacks occupied 10.83\%; from station Jinghe, a total of 818 cases were observed, and of these positive feedbacks occupied $12.96 \%$, and negative feedbacks occupied $8.80 \%$; from station ZBYN, a total of 916 cases were observed, and of these positive feedbacks occupied $9.72 \%$, and negative feedbacks occupied $7.97 \%$; from station ZLYA, a total of 1160 cases were observed, and of these positive feedbacks occupied 7.07\%, negative feedbacks occupied 7.50\%; from station Yuzhong, a total of 909 cases were observed, and of these positive feedbacks occupied $6.49 \%$, and negative feedbacks occupied $11.22 \%$; from station Yinchuan, a total of 72 cases were observed, and of these, positive feedbacks occupied $6.94 \%$, and negative feedbacks occupied $8.33 \%$; from station Xining, a total of 85 cases were observed, and of these positive feedbacks occupied $3.53 \%$,and negative feedbacks occupied 3.53\%; and from station Pingliang, a total of 137 cases were observed, and of these positive feedbacks occupied 5.11\%, and negative feedbacks occupied $4.38 \%$. The total percentage of positive feedbacks and negative feedbacks were $8.42 \%$ and $9.04 \%$ respectively. Due to the limited amount of data, the probability distributions of station Yinchuan, Xining and Pingliang probably could not represent the climate-scale situation. However, we can still analyze the positive and negative distributions based on the existing results. Station $\mathrm{ZBHH}$, Yinchuan, Yuzhong present much more negative feedbacks; station 
ZBYN, Jinghe and Pingliang present much more positive feedbacks (Figure 3). As depicted in Figure 3, negative feedback is predominant in the north and west portion of the Loess Plateau; in the south and east portion, positive feedback is predominant.

Considering China's Grain for Green project, which has been in operation since 1999, the soil moisture in this region has also changed dramatically over the last few decades. In later work, we will further verify the applicability of this study's results by using precipitation data in the Loess Plateau region.

\section{Discussion and Conclusions}

In this study, we explored the feedback between soil moisture and atmosphere on the Loess Plateau using the CTP-HI $\mathrm{HI}_{\text {low }}$ framework, which was initiated by Findell and Eltahir [32]. We evaluated the modified one-dimensional model and calculated the new $\mathrm{CTP}-\mathrm{HI}_{\mathrm{low}}$ thresholds based on the modified slab model's outcomes. Using the new

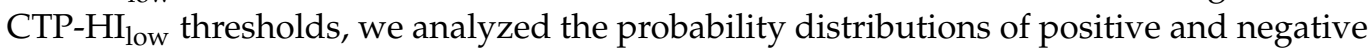
feedbacks with long-time scales sounding data.

In the original work of Findell [28], in the United States, for atmosphere-controlled cases: when $\mathrm{HI}_{\text {low }}<5{ }^{\circ} \mathrm{C}, \mathrm{CTP}<0 \mathrm{~J} / \mathrm{kg}$, shallow clouds occur over both soil conditions; when $\mathrm{HI}_{\text {low }}<5{ }^{\circ} \mathrm{C}, \mathrm{CTP}>0 \mathrm{~J} / \mathrm{kg}$, rain occurs over both soil conditions; and when $\mathrm{HI}_{\text {low }}>15^{\circ} \mathrm{C}$, any CTP, no convection occurs over either soil condition. For soil moisturecontrolled cases: when $5{ }^{\circ} \mathrm{C}<\mathrm{HI}_{\text {low }}<10{ }^{\circ} \mathrm{C}, 0<\mathrm{CTP}<200 \mathrm{~J} / \mathrm{kg}$, there is a wet soil advantage, i.e., rain or shallow clouds over wet soils only; when $10{ }^{\circ} \mathrm{C}<\mathrm{HI}_{\mathrm{low}}<15^{\circ} \mathrm{C}$, $100<\mathrm{CTP}<200 \mathrm{~J} / \mathrm{kg}$, there is a transition zone, and any outcomes possible; and when $10{ }^{\circ} \mathrm{C}<\mathrm{HI}_{\text {low }}<15{ }^{\circ} \mathrm{C}, 200<\mathrm{CTP}<400 \mathrm{~J} / \mathrm{kg}$, there is a dry soil advantage, i.e., rain or shallow clouds over dry soils only.

From the work of Tuinenburg et al. [22], who calculated the new CTP-HI $\mathrm{I}_{\text {low }}$ space in India for positive feedbacks and negative feedbacks, we can learn that: when $7<\mathrm{HI}_{\text {low }}<12{ }^{\circ} \mathrm{C}$, $0<\mathrm{CTP}<200 \mathrm{~J} / \mathrm{kg}$, positive feedbacks can occur; and when $11<\mathrm{HI}_{\text {low }}<16{ }^{\circ} \mathrm{C}, 200<\mathrm{CTP}$ $<500 \mathrm{~J} / \mathrm{kg}$, negative feedbacks can occur.

Comparing our results with the thresholds stated above, we find that the $\mathrm{HI}_{\text {low }}$ values are higher in our work. Since the $\mathrm{HI}_{\text {low }}$ index represents low-level atmospheric humidity, and our study area is located in the semi-arid area, this result is reasonable and we will apply these new thresholds for our future research work.

Because of the lack of observational data for use in evaluating the realism of modelbased land-atmosphere feedback, so far, the regions using a one-dimensional boundary layer model to calculate the CTP-HI $\mathrm{H}_{\text {low }}$ thresholds are mainly the United States and India. Ferguson and Wood [29] revised the CTP-HI $\mathrm{H}_{\text {low }}$ classification framework globally using the combinations of methods and data sources with remote sensing data, and they found vast differences among 20 climatic regions and three GLACE coupling hot spots. In recent research work, Wakefield et al. [37] investigated changes in the covariance of soil moisture and the atmospheric low-level thermodynamic profile during seasonal hydrometeorological extremes by using the CTP-HI ${ }_{\text {low }}$ framework in the United States. Bhowmick [38] demonstrated that this framework lacked generality and that solutions were empirically derived based on one-dimensional modelling and observations, which varied from place to place. Therefore, it is very necessary to use our valuable observed radiosonde data on the Loess Plateau for one-dimensional model analysis.

During the model simulation period, the boundary layer sometimes grew up to 400 $\mathrm{hPa}$ or even $500 \mathrm{hPa}$ above the ground surface. Thereby, we changed the ranges at which the CTP was calculated and found no improvement in classification. Therefore, we did not change the calculation ranges of the $\mathrm{CTP}$ and $\mathrm{HI}_{\mathrm{low}}$ in this work. Moreover, the wind may enhance or diminish convection, as stated by Findell [28]. However, in this work, we emphasized the heat fluxes' impacts and ignored the influences of wind. As we discussed, the influences of wind or other factors which can impact the soil moisture-atmosphere feedback need to be researched in the future. The results of this paper are as follows: 
(1) We concluded the new CTP-HI $\mathrm{H}_{\text {low }}$ thresholds in the Loess Plateau based on the modified slab model. For atmosphere-controlled cases: when $\mathrm{HI}_{\text {low }}<10^{\circ} \mathrm{C}, \mathrm{CTP}<100 \mathrm{~J} / \mathrm{kg}$, shallow clouds occur over both soil conditions; when $\mathrm{HI}_{\mathrm{low}}<10^{\circ} \mathrm{C}, \mathrm{CTP}>100 \mathrm{~J} / \mathrm{kg}$, rain occurs over both soil conditions; and when $\mathrm{HI}_{\text {low }}>26{ }^{\circ} \mathrm{C}$, any CTP, no convection occurs over either soil condition. For soil moisture-controlled cases: when $10{ }^{\circ} \mathrm{C}<\mathrm{HI}_{\text {low }}<16^{\circ} \mathrm{C}, \mathrm{CTP}<100 \mathrm{~J} / \mathrm{kg}$, shallow clouds occur over wet soils; $10^{\circ} \mathrm{C}<\mathrm{HI}_{\text {low }}<16^{\circ} \mathrm{C}, 100<\mathrm{CTP}<240 \mathrm{~J} / \mathrm{kg}$, there is a wet soil advantage, i.e., rain or shallow clouds over wet soils only; when $16^{\circ} \mathrm{C}<\mathrm{HI}_{\text {low }}<26^{\circ} \mathrm{C}, 100<\mathrm{CTP}<240 \mathrm{~J} / \mathrm{kg}$, there is a transition zone, and any outcome is possible; and when $16{ }^{\circ} \mathrm{C}<\mathrm{HI}_{\text {low }}<26^{\circ} \mathrm{C}$, $240<\mathrm{CTP}<400 \mathrm{~J} / \mathrm{kg}$, there is a dry soil advantage, i.e., rain or shallow clouds over dry soils only.

(2) The probability distributions of atmosphere-controlled cases and soil moisturecontrolled cases of model outcomes were $69.83 \%$ and $30.17 \%$, respectively. The probability distributions of the wet soil advantage cases and dry soil advantage cases of model outcomes showed some difference from the new CTP-HI $\mathrm{H}_{\text {low }}$ diagnostic results. For model outcomes, it seemed like stations ZBHH, Jinghe, ZBYN, and ZLYA had more negative feedbacks, and the total percentage indicated that more negative feedbacks existed in the Loess Plateau. For new CTP-HI ${ }_{\text {low }}$ diagnostic results, stations ZBHH, Yinchuan, and Yuzhong present much more negative feedbacks; and stations ZBYN, Jinghe and Pingliang present much more positive feedbacks. In total, negative feedback is predominant in the northern and western portion of the Loess Plateau; in the southern and eastern portion, positive feedback is predominant.

Author Contributions: Conceptualization, X.M. and Y.M.; methodology, X.M.; software, Y.M.; validation, Y.M., X.M. and Y.A.; formal analysis, Y.M.; investigation, Y.M. and S.L.; resources, Y.Y. and J.L.; data curation, Y.Y. and J.L.; writing-original draft preparation, X.M. and S.L.; writing-review and editing, X.M. and Y.M.; visualization, Y.M. and J.X.; supervision, X.M. and G.L.; project administration, X.M.; funding acquisition, X.M. All authors have read and agreed to the published version of the manuscript.

Funding: This study was conducted under the auspices of the Chinese National Science Foundation Programs: 91837209, 41822501, 41975014, 42075042; The Science and Technology Research Plan of Gansu Province: 20JR10RA070; the Chinese Academy of Youth Innovation and Promotion, CAS: Y201874; iLEAPs (integrated Land Ecosystem-Atmosphere Processes Study-iLEAPS), and the National Key Research and Development Program of China (2016YFB0501303).

Acknowledgments: Thanks to the University of Wyoming for its open-source radiosonde soundings data.

Conflicts of Interest: The authors declare no conflict of interest.

\section{References}

1. Seneviratne, S.I.; Corti, T.; Davin, E.L.; Hirschi, M.; Jaeger, E.B.; Lehner, I.; Orlowsky, B.; Teuling, A.J. Invetigating soil moisture climate interactions in a changing climate: A review. Earth-Sci. Rev. 2010, 99, 125-161. [CrossRef]

2. Santanello, J.A.; Dirmeyer, P.A.; Ferguson, C.R.; Findell, K.L.; Tawfik, A.B.; Berg, A.; Ek, M.; Gentine, P.; Guillod, B.P.; van Heerwaarden, C.; et al. Land-Atmosphere interactions in the LoCo perspective. Bull. Am. Meteorol. Soc. 2018, 99, 1253-1272. [CrossRef]

3. Shuttleworth, W. The Modellion concept. Rev. Geophy. 1991, 29, 585-606. [CrossRef]

4. Brubaker, K.L.; Entekhabi, D. Analysis of feedback mechanisms in land-atmosphere Interaction. Water Resour. Res. 1996, 32, 1343-1357. [CrossRef]

5. Findell, K.L.; Eltahir EA, B. An analysis of the soil moisture-rainfall feedback, based on direct observations from Illinois. Water Resour. Res. 1997, 33, 725-735. [CrossRef]

6. Nicholson, S.E. Land surface processes and Sahel climate. Rev. Geophy. 2000, 38, 117-139. [CrossRef]

7. Vereecken, H.; Huisman, J.A.; Bogena, H.; Vanderborght, J.; Vrugt, J.A.; Hopmans, J.W. On the value of soil moisture measurements in vadose zone hydrology: A review. Water Resour. Res. 2008, 44, W00D06. [CrossRef]

8. Sanchez-Mejia, Z.M.; Papuga, S.A. Observations of a two-layer soil moisture influence on surface energy dynamics and planetary boundary layer characteristics in a semiarid shrubland. Water Resour. Res. 2014, 50, 306-317. [CrossRef]

9. Li, K.; Zhang, J.; Wu, L. Assessment of soil moisture temperature feedbacks with the CCSM-WRF model system over east Asia. J. Geophys. Res.-Atmos. 2018, 123, 6822-6839. [CrossRef] 
10. Yuan, G.; Zhang, L.; Liang, J.; Cao, X.; Guo, Q.; Yang, Z. Impacts of initial soil moisture and vegetation on the diurnal temperature range in arid and semiarid regions in China. J. Geophys. Res.-Atmos. 2017, 122, 11568-11583. [CrossRef]

11. Huang, J.; van den Dool, H.M.; Georgakakos, K.P. Analysis of model-calculated soil moisture over the United States (1931-1993) and applications to long-range temperature forecasts. J. Clim. 1996, 9, 1350-1362. [CrossRef]

12. Bosilovich, M.G.; Chern, J. Simulation of water sources and precipitation recycling for the MacKenzie, Mississippi, and Amazon River basins. J. Hydrometeorol. 2006, 7, 312-329. [CrossRef]

13. Clark, R.T.; Brown, S.J.; Murphy, J.M. Modeling northern hemisphere summer heat extreme changes and their uncertainties using a physics ensemble of climate sensitivity experiments. J. Clim. 2006, 19, 4418-4435. [CrossRef]

14. Namias, J. The annual course of month-to-month persistence in climatic anomalies. Bull. Am. Meteorol. Soc. 1952, 33, 279-285. [CrossRef]

15. Zaitchik, B.F.; Macalady, A.K.; Bonneau, L.R.; Smith, R.B. Europe's 2003 heat wave: A satellite view of impacts and landatmosphere feedbacks. Int. J. Climatol. 2006, 26, 743-769. [CrossRef]

16. Welty, J.; Zeng, X. Does soil moisture affect warm season precipitation over the southern Great Plains? Geophys. Res. Lett. 2018, 45, 7866-7873. [CrossRef]

17. Moon, H.; Guillod, B.P.; Gudmundsson, L.; Seneviratne, S.I. Soil moisture effects on afternoon precipitation occurrence in current climate models. Geophys. Res. Lett. 2019, 46, 1861-1869. [CrossRef]

18. Dirmeyer, P.A. The hydrologic feedback pathway for land-climate coupling. J. Hydrometeorol. 2006, 7, 857-867. [CrossRef]

19. Van der Ent, R.J.; Savenije, H.H.G.; Schaefli, B.; Steele-Dunne, S.C. Origin and fate of atmospheric moisture over continents: Origin and fate of atmospheric moisture. Water Resour. Res. 2010, 46, W09525. [CrossRef]

20. Eltahir, A.B.; Bras, R.L. Precipitation recycling. Rev. Geophy. 1996, 34, 367-378. [CrossRef]

21. Chen, L.; Dirmeyer, P.A. Impacts of land-use/land-cover change on afternoon precipitation over North America. J. Clim. 2017, 30, 2121-2140. [CrossRef]

22. Tuinenburg, O.A.; Hutjes, R.W.A.; Jacobs, C.M.J.; Kabat, P. Diagnosis of local land-atmosphere feedbacks in India. J. Clim. 2011, 24, 251-266. [CrossRef]

23. Charney, J.G. Dynamics of deserts and drought in the Sahel. Q. J. R. Meteorol. Soc. 1975, 101, 193-202. [CrossRef]

24. Dirmeyer, P.A. Using a global soil wetness dataset to improve seasonal climate simulation. J. Clim. 2000, 13, 2900-2922. [CrossRef]

25. Koster, R.D.; Sud, Y.C.; Guo, Z.; Dirmeyer, P.A.; Bonan, G.; Oleson, K.W.; Chan, E.; Verseghy, D.; Cox, P.; Davies, H.; et al. GLACE: The Global Land-Atmosphere Coupling Experiment. Part I: Overview. J. Hydrometeorol. 2006, 7, 590-610. [CrossRef]

26. Guo, Z.; Dirmeyer, P.A.; Koster, R.D.; Sud, Y.C.; Bonan, G.; Oleson, K.W.; Chan, E.; Verseghy, D.; Cox, P.; Gordon, C.T.; et al. GLACE: The global land-atmosphere coupling experiment. Part II: Analysis. J. Hydrometeorol. 2006, 7, 611-625. [CrossRef]

27. Chen, Y.; Wang, K.; Lin, Y.; Shi, W.; Song, Y.; He, X. Balancing green and grain trade. Nat. Geosci. 2015, 8, 739-741. [CrossRef]

28. Findell, K.L. Atmospheric Controls on Soil Moisture Boundary Layer Interactions. Ph.D. Thesis, Massachusetts Institute of Technology, Cambridge, MA, USA, 2001; p. 172.

29. Ferguson, C.R.; Wood, E.F. Observed land-atmosphere coupling from satellite remote sensing and reanalysis. J. Hydrometeorol. 2011, 12, 1221-1254. [CrossRef]

30. Kim, C.P.; Entekhabi, D. Feedbacks in the land-surface and mixed-layer energy budgets. Bound. -Layer Meteorol. 1998, 88, 1-21. [CrossRef]

31. Kim, C.P.; Entekhabi, D. Impact of soil heterogeneity in a mixed layer model of the planetary boundary layer. Hydrolog. Sci. J. 1998, 43, 633-658. [CrossRef]

32. Findell, K.L.; Eltahir, E.A.B. Atmospheric controls on soil moisture-boundary layer interactions. Part I: Framework development. J. Hydrometeorol. 2003, 4, 552-569. [CrossRef]

33. Battan, L.J. Radar Observations of the Atmosphere; University of Chicago Press: Chicago, IL, USA, 1973 ; p. 324.

34. Showalter, A.K. A stability index for thunderstorm forcasting. Bull. Am. Meteorol. Soc. 1953, 34, 250-252. [CrossRef]

35. Clapp, R.B.; Hornberger, G.M. Empirical equations for some soil hydraulic properties. Water Resour. Res. 1978, 14, 601-604. [CrossRef]

36. Chen, X.; Yu, Y.; Chen, J.B.; Zhang, T.T.; Li, Z.C. Study of Estimation of Soil Heat Flux at a Wheat Field in Semi-Arid Area of Loess Plateau. Plateau Meteor. 2014, 33, 1514-1525.

37. Wakefield, R.A.; Basara, J.B.; Furtado, J.C.; Illston, B.G.; Ferguson, C.R.; Klein, P.M. A Modified Framework for Quantifying Land-Atmosphere Covariability during Hydrometeorological and Soil Wetness Extremes in Oklahoma. J. Appl. Meteorol. Climatol. 2019, 58, 1465-1483. [CrossRef]

38. Bhowmick, M. Impact of Soil Moisture Variability on Convective Rainfall Activity over the Indian Sub-Continent. Ph.D. Thesis, The University of Leeds, Leeds, UK, 2016; p. 135. 